\title{
Presentación del mapa de riesgo de nuestra unidad de hemodiálisis
}

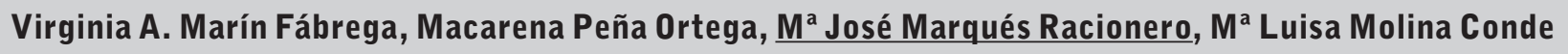

\author{
Club de Hemodiálisis Nefrolinares. Jaén
}

\section{Introducción:}

La elaboración del mapa de riesgo de nuestra unidad pretende determinar y analizar cuáles son los principales riesgos a los que están expuestos nuestros pacientes así como la aplicación de planes de mejora para la reducción o incluso eliminación de los mismos.

\section{Objetivo:}

Presentación del mapa de riesgo de nuestra unidad de hemodiálisis (HD) en centro periférico.

\section{Desarrollo:}

\section{$1^{\text {a }}$ ETAPA.}

Constituimos un grupo de trabajo formado por tres Diplomadas Universitarias en Enfermería (DUE), dos Auxiliares de Enfermería (AE) y un Nefrólogo (N), nombrado este último como coordinador del equipo. Planificamos una dinámica de trabajo consistente en reuniones periódicas mensuales.

\section{$2^{\text {a }}$ ETAPA.}

Diseñamos una matriz de riesgo basada fundamentalmente en la técnica de brainstorming durante las reuniones planificadas, consensuando después lo aportado de forma individual. Tras las reuniones identificamos cuáles son los pacientes más susceptibles de sufrir un evento adverso en nuestra unidad: personas con movilidad reducida y de edad avanzada y cuáles son las circunstancias y lugares con mayor riesgo de amenaza para los pacientes: área de recepción, zona del peso y puertas.

\section{$3^{\text {a ETAPA. }}$}

Dividimos el proceso de atención al paciente en tres etapas: PreHD+Conexión.- HD.- PostHD+Desconexión.

Realizamos un Análisis Modal de Fallos y Efectos (AMFE) para cada etapa.

1. Efecto Adverso: Riesgo de caídas.

Fallo/Causa: Desnivel en el margen del peso, puertas abatibles y subida y bajada de la ambulancia.

Gravedad $^{1}$ : (G) Moderada.

$\mathrm{N}^{\circ}$ Pacientes Afectados 2 : ( $\left.\mathrm{N}^{\circ}\right)$ Alta.

Acciones Correctivas: Corregir el desnivel del peso, puertas antipánico manipuladas por el personal, acompañamiento por los celadores.

Responsables: Diplomados Universitarios en Enfermería (DUEs), Auxiliares de Enfermería (AEs) y Celadores (Cs).

Etapa: PreHD y PostHD.

2. Efecto Adverso: Calambres intraHD.

Fallo/Causa: Nivel de sodio bajo en el líquido de HD, ultrafiltración excesiva. G Moderada Nº Moderada

Acciones Correctivas: Adecuar el nivel de sodio del líquido de HD, no programar una ultrafiltración horaria que supere el $10 \%$ del peso total del paciente. Responsables: Nefrólogos (Ns) y DUEs.

Etapa: IntraHD yPostHD.

3. Efecto Adverso: Riesgo de contagio por virus hepatitis C.

Fallo/Causa: Compartir sala de espera y transporte. G Muy alta No Muy baja.

Acciones Correctivas: Pacientes positivos permanecerán en su sala hasta llegada transporte.

Responsables: DUEs, Aes y Cs. ETAPA PostHD. 
4. Efecto Adverso: Vulnerabilidad intimidad paciente.

Fallo/Causa: Visita médica en sala HD. G Muy baja ${ }^{\circ}$ Muy alta.

Acciones Correctivas: Hablar la información importante para el paciente en el despacho.

Responsables: Ns.

Etapa: IntraHD.

5. Efecto Adverso: Vulnerabilidad protección datos.

Fallo/Causa: Historias clínicas al alcance de los pacientes. G Moderada No Muy alta.

Acciones Correctivas: Informatizar los máximos datos posibles.

Responsables: Ns y DUEs.

Etapa: IntraHD.

6. Efecto Adverso: Error administración fármacos.

Fallo/Causa: Elevada carga de trabajo. G Muy alta $\mathrm{N}^{\circ}$ Muy baja.

Acciones Correctivas: Cumplir reglas para administración segura de medicamentos.

Responsables: DUEs.

Etapa: IntraHD.

(1) Escala de referencia del 1 (menor gravedad) hasta el 10 (mayor gravedad). Anexo 1.
(2) Escala de referencia del 1 (menor gravedad) hasta el 10 (mayor gravedad). Anexo 2.

$4^{\text {a }}$ ETAPA.

Acciones correctivas para cada fallo.

$5^{\text {a ETAPA. }}$

Evaluamos los resultados.

\section{Referencias Bibliográficas}

1. Muñoz Poyatos J. Método AMFE aplicado a Hemodiálisis. XIX Seminario Español EDTNA/ERCA. Barcelona. 3 junio 2011.

2. Mapa de riesgos del Bloque Quirúrgico H. Virgen de la Victoria de Málaga. J. del Río Mata (coordinador).et al. H.U. Virgen de la Victoria. SAS. Consejería de Salud. Junta de Andalucía. Abril 2010. ISBN: 978-84-614-1962-3.

3. El análisis modal de fallos y efectos (AMFE). Una herramienta muy útil para la seguridad del paciente. Pedro Ruiz López y Carmen González RodríguezSalinas. Jano 27 de junio-3 julio 2008. N 1702. 